\title{
STRATEGI UNTUK MENINGKATKAN PASAR PRODUK ALAT HISPATOLOGI (MERK SAKURA) : STUDI KASUS PT. FAJAR MAS MURNI
}

\author{
Anton Sukoco (1), Yusak Anshori (2) \\ Universitas Airlangga (1), Universitas Nadhatul Ulama \\ Surabaya (2) \\ | anton.sukoco-2017@feb.unair.ac.id ${ }^{1}$, \\ yusak.ashori@unusa.ac.id²
}

Abstrak: Tujuan dari penelitian ini adalah untuk mengevaluasi strategi pemasaran yang langsung mengenai pemimpin pasar dengan tujuan mendapatkan strategi pemasaran untuk meningkatkan pangsa pasar dan menjadi pemimpin pasar. Penelitian ini menggunakan pendekatan kualitatif dan kuantitatif. Analisis yang digunakan adalah analisis deskriptif menggunakan instrumen analisis SWOT disertai dengan perhitungan IFAS dan EFAS. Sumber data dan jenis data penelitian terdiri dari data primer dan data sekunder. Data primer diperoleh dari hasil diskusi kelompok fokus, wawancara mendalam dan kuesioner. Sedangkan data sekunder diperoleh dari laporan keuangan dan artikel serta literatur yang relevan. Hasil pengayaan strategi dengan mengggunakan analisis SWOT pada pendekatan kuantitatif diperoleh bahwa posisi perusahaan berada pada kuadran 3 yakni kuadran WO dengan koordinat (0,$63 ;+1,47$ ) sehingga perusahaan seharusnya memasuki strategi turnaround, yaitu mengubah strategi pemasaran mereka dari hit langsung menjadi pemimpin pasar dengan meningkatkan layanan purna jual, meningkatkan kualitas produk mereka, ekuitas merek, dukungan dari manajemen puncak dan menempatkan unit di Rumah 
Sakit Pendidikan. Penelitian ini dapat memberikan gambaran umum kepada praktisi dalam pengambilan keputusan strategis pemasaran.

Keywords: penantang pasar (market challenger), analisis SWOT, Internal Factor Analysis (IFAS), Eksternal Factor Analysis (EFAS), strategi pemasaran

\section{Pendahuluan}

Kanker merupakan penyakit yang menyebabkan tingkat kematian utama di seluruh dunia. Pada tahun 2012 saja, korban kanker sebesar 8,2 juta jiwa dimana kanker paru, hati, perut, kolorektal dan kanker payudara merupakan jenis kanker yang terbesar yang menyebabkan kematian setiap tahunnya. Ada terdapat lebih dari 30 persen angka kematian yang diakibatkan oleh kanker setidaknya disebabkan oleh beberapa faktor yaitu, pertama, indeks berat badan yang overload, kedua, kurang mengonsumsi buah dan sayur, ketiga, kurangnya beraktivitas fisik; keempat, merokok; kelima, mengonsumsi alkohol yang berlebihan. Berdasarkan faktor penyebab kanker tersebut, ternyata merokok merupakan faktor utama dan berdasarkan data, merokok pula yang mengakibatkan 20 persen orang meninggal, sedangkan terdapat 70 persen kematian disebabkan oleh kanker paru-paru. Terdapat lebih dari 60 persen kasus baru dan sekitar 70 persen kematian terjadi yang diakibatkan oleh kanker setiap tahunnya terjadi di Afrika, Asia dan Amerika Tengah dan Amerika Selatan. Dari data lainnya menunjukkan bahwa data penderita kanker juga meningkat dari 14 juta pada 2012 menjadi 22 juta dalam dua dekade berikutnya ${ }^{1}$.

Sebaran penyakit tersebut khusus di Indonesia juga tidak kalah memprihatinkan. Berdasarkan data riset

${ }^{1}$ Kementrian Kesehatan RI. 2015. Pusat Data Dan Informasi Kementrian Kesehatan RI. 
kesehatan dasar pada tahun 2013, Badan Litbangkes Kementerian Kesehatan RI merilis terdapat 1,4 persen atau diperkirakan sebanyak 347.742 orang. Berdasarkan sebaran data per-propinsi, propinsi DI. Yogyakarta menduduki peringkat tertinggi, yaitu 4,1\%, kemudian diikuti oleh propinsi Jawa Timur di peringkat kedua, dan propinsi Jawa Tengah di peringkat ketiga yaitu sebanyak 61.230 jiwa. Berdasarkan data tersebut, Rumah Sakit di Indonesia pun berupaya meningkatkan mutu pelayanannya, Pemerintah melalui Kementerian Kesehatan menerbitkan Peraturan tentang Klasifikasi dan Perizinan Rumah Sakit yang mengatur bahwa Rumah Sakit tipe 'B' sesuai pasal 26 no. 4 harus mempunyai pelayanan medik spesialis penunjang, yang salah satunya adalah Patologi Anatomi². Spesialis Patologi Anatomi mendiagnosis penyakit seseorang berdasar hasil pemeriksaan laboratorium. Adapun jenis pemeriksanaan laboratorium patologi anatomi diantaranya adalah pemeriksaan histologi (morfologi jaringan) atau Sitologi. Hal yang berkaitan dengan sitologi ialah histopatologi. Histopatologi sendiri adalah ilmu yang merupakan cabang biologi yang mempelajari fungsi jaringan serta kondisinya yang berhubungan dengan penyakit. Metode pemeriksaan histopatologi dapat dilakukan dengan memeriksa terhadap hal-hal yang dinilai abnormal pada level jaringan.

Adanya peningkatan tren jumlah penderita kanker dari tahun ke tahun, dan adanya upaya peningkatan kualitas mutu layanan Rumah Sakit tipe 'B' dalam mendiagnosis penyakit kanker, maka perlu adanya peningkatan sarana dan prasarana guna menunjang dan perlengkapan pengobatan di Rumah Sakit. PT. Fajar Mas Murni (FMM) yang merupakan perusahaan dagang

2 Kementrian Kesehatan Republik Indonesia. 2014. Peraturan Menteri Kesehatan Republik Indonesia No 56 Tahun 2014.

http://www.yankes.kemkes.go.id/assets/downloads/PMK\%20No.\%2056\%20t tg\%20Klasifikasi\%20dan\%20Perizinan\%20Rumah\%20Sakit.pdf. 
nasional yang telah berusia 40 tahun dan bergerak dalam bidang general importir sejak tahun 1973, telah menangani produk-produk manufaktur, oildan gas, dan tambang. Selain bidang bisnis tersebut pada kurun waktu 15 tahun terakhir sejak tahun 2003, PT. FMM telah merambah ke bidang bisnis pasar pendidikan dan rumah sakit, dimana produk yang sedang dikenalkan kepada pasar adalah merk Sakura Finetek Japan. Sakura Finetek merupakan pabrikan untuk produk peralatan medis seperti tissue processor, mikroton, embedding tissue console system, auto stainer, dan covar slipping, yang diproduksi oleh negara asalnya, Jepang, kemudian dipasarkan ke sebagian belahan dunia termasuk salah satunya ke Indonesia. Namun dengan jenis produk yang serupa terdapat kompetitor yaitu Leica dan Thermo yang diageni berturut-turut oleh PT. Biogen Scientific dan PT Enseval Medika Prima.

Berdasarkan data yang dihimpun dari internal PT. FMM, diperoleh bahwa market share produk merk Sakura merupakan produk dengan kategori market challenger, karena memiliki pangsa pasar masih dibawah $40 \%$ sedangkan pangsa pasar market leader adalah sebesar $40 \%$. Hal tersebut terbukti pada laju perkembangan market share PT. FMM berturut-turut di tahun 2016, 2017, dan 2018 belum pernah sekalipun mencapai angka $40 \%$, dan angka tersebut menjadi acuan untuk dapat bersaing dengan industri sejenis yang telah menjadi market ${ }^{3}$. Pada sudut pandang lain, sebuah produk yang tergolong market challenger kadang menyerang market leader dan para pesaingnya untuk menaikkan market share. Sehingga jika ingin meningkatkan market share sebuah perusahaan harus mempunyai strategi pemasaran yang efektif, yaitu yang mampu diterima pasar dengan baik. Adanya peningkatan market share Sakura Finetek dan menjadikannya market leader berarti

\footnotetext{
3 Kotler, Philip, and Kevin Lane Keller. (2016). Pearson Marketing Management 14e. Pearson Education Limited.
} 
akan menaikkan image produk dan image perusahaan. Sehingga dengan meningkatnya image tersebut akan meningkatkan kepercayaan sales force kepada calon pengguna produk dan sekaligus manfaat dari sisi perusahaan adalah perusahaan mampu menjadi pilihan para calon principal di sektor bisnis alat alat kesehatan dan laboratorium. Selain itu manfaat mempunyai pangsa pasar terbesar adalah memimpin perusahaan lainnya dalam hal perubahan harga, pengenalan produk baru, menunjukkan kekuatan perusahaan dalam cakupan distribusi dan intensitas promosi sekaligus akan mendapatkan keuntungan paling banyak apabila ukuran pasar meluas ${ }^{4}$. Atas dasar ulasan latar belakang itulah maka sangat menarik untuk dilakukan penelitian mengenai strategi pemasaran untuk meningkatkan pangsa pasar (market share) alat kesehatan dan menjadi pemimpin pasar.

Adapun penelitian terdahulu yang berkaitan dengan peningkatan market share, antara lain: penelitian yang dilakukan oleh Rahmayati HM (2015) dengan judul Analisis SWOT dalam Menentukan Strategi Pemasaran Udang Beku PT. Mustika Mina Nusa Aurora Tarakan, Kalimantan Utara ${ }^{5}$. Kemudian penelitian yang dilakukan oleh Iman Sulaeman (2016) dengan judul Kualitas Pelayanan dan Strategi Marketing Terhadap Kepuasan Pada Suria City Hotel Bandung ${ }^{6}$.

Penelitian yang dilakukan oleh Dr. Fareha Zafar, Sman Babar, and Hina Abbas (2013) dengan judul The Art of Strategic Management - a key success in corporate sector ${ }^{7}$. Penelitian yang dilakukan oleh Aries Susanty dan

\footnotetext{
${ }^{4}$ Ibid.

5 Rahmayati HM. (2015)." Analisis SWOT dalam Menentukan Strategi Pemasaran Udang Beku PT. Mustika Mina Nusa Aurora Tarakan, Kalimantan Utara". Jurnal Galung Tropika. Vol.4 No.1. hal.60-67.

6 Iman Sulaeman. (2016)." Kualitas Pelayanan dan Strategi Marketing Terhadap Kepuasan Pada Suria City Hotel Bandung". Jurnal Lentera Bisnis. Vol.5 No.2. hal. 77-103.

7 Dr. Fahreza Zafar, Sman Babar, dkk. (2013)." The Art of Strategic
} 
Woro Adiati (2014) dengan judul Pemilihan Strategi Pemasaran di Kampoeng Kopi Banaran Menggunakan Pendekatan Metode Analytical Network Process (ANP) dan Technique for Order Preference by Similarity To an Ideal Solution (TOPSIS) ${ }^{8}$. Penelitian yang dilakukan oleh Ifediora Christian Osita, Onyebuchi R., Nzekwe Zustina (2014) dengan judul Organization's stability and productivity the role of SWOT analysis an acronym for strenght, weakness, oppurtunities and threat ${ }^{9}$.

Selanjutnya, penelitian yang dilakukan oleh llyas, Sarika Zuhri, Tri Asih Wulandari and Hasan Yudhi Sastra (2018) dengan judul Marketing Strategy Determination by SWOT and ANP Approaches on Aceh Songket SmallMedium Enterprises ${ }^{10}$. Penelitian yang dilakukan oleh Siti Muhimatul Khoiroh (2017) dengan judul Optimalisasi Pengembangan Kampung Industri Batik Tulis Daerah berdasarkan Mapping Value Chain ${ }^{11}$.

Penelitian yang dilakukan oleh Al-Refaie, A. Sy, E, Rawabdeh, I, Alaween, W (2016) dengan judul Integration of SWOT and ANP for effective strategic planning in the cosmetic industry ${ }^{12}$. Kemudian penelitian yang dilakukan

Management - a key success in corporate sector". EuropeanJournal of Research and Reflection in Management Sciences. Vol.1 No.1. Hal.15-24.

${ }^{8}$ Aries Susanty \& Woro Widiati (2014). "Pemilihan Strategi Pemasaran di Kampoeng Kopi Banaran Menggunakan Pendekatan Metode Analytical Network Process (anp) dan Technique for Order Preference by Similarity To an Ideal Solution (TOPSIS)". J@TI Undip. Vol IX No 3. Hal.163-172.

${ }^{9}$ Ifediora Christian Osita \& Idoko Onyebuchi R., dkk. (2014)." Organization's stability and productivity the role of SWOT analysis an acronym for strenght, weakness, oppurtunities and threat". International Journal of Innovative and Applied Research. Vol.2 No.9. Hal.23-32.

10 Ilyas \& Sarika Zuhri, dkk. (2018)." Marketing Strategy Determination by SWOT and ANP Approaches on Aceh Songket Small-Medium Enterprises". International Journal of Conceptionson Computing and Information Technology. Vol.6 No.1. Hal.8-13.

11 Siti Muhimatul Khoiroh (2017). "Optimalisasi Pengembangan Kampung Industri Batik Tulis Daerah berdasarkan Mapping Value Chain". Surakarta. Seminar dan Konferensi Nasional IDEC 2017.

${ }^{12}$ Al-Refaie, A \& Sy, E, dkk. (2016). "Integration of SWOT and ANP for effective strategic planning in the cosmetic industry". Advancesin Production Volume 4 , No. 2, Juni 2020 
oleh Živan Živković, Djordje Nikolić, Predrag Djordjević, Ivan Mihajlović, Marija Savić (2015) dengan judul Analytical Network Process in the Framework of SWOT Analysis for Strategic Decision Making (Case Study: Technica/Faculty in Bor, University of Belgrade, Serbia) ${ }^{13}$.

\section{Landasan Teori}

Strategi

Strategi adalah perencanaan utama yang sistematis dan teratur sehingga dapat mewujudkan hasil yang ditetapkan berdasarkan misi yang dimiliki oleh perusahaan ${ }^{14}$. Adapula definisi lain dari strategi adalah serangkaian ulasan keputusan yang dilakukan atas dasar tindakan mendasar yang telah disusun oleh manajemen struktural tingkat atas yang diwujudkan dan dilakukan agar tujuan perusahaan tercapai ${ }^{15}$. Atau terdapat pula tiga pendekatan atas strategi yaitu deklarasi, perspektif faktor keberhasilan dan cara agar tercipta tujuan perusahaan ${ }^{16}$.

\section{Manajemen Strategik}

Seni pengelolaan yang sistematis dapat dikatakan juga sebagai manajemen strategik adalah proses pengambilan keputusan yang menggunakan dan mengalokasikan waktu yang relatif lama ${ }^{17}$. Hal ini juga

Engineering \& Management. Vol.11 No.1. Hal.49-58.

${ }^{13}$ Živan Živković \& Djordje Nikolić, dkk. (2015)." Analytical Network Process in the Framework of SWOT Analysis for Strategic Decision Making (Case Study: Technical Faculty in Bor, University of Belgrade, Serbia). Acta Polytechnica Hungarica. vol.12 No.7. Hal.199-216.

${ }^{14}$ Rangkuti, F.(2017)."Teknik Membedah Kasus Bisnis Analisis SWOT, Cara Perhitungan Bobot, Rating, dan OCAL". Jakarta. PT Gramedia Pustaka Utama. ${ }^{15}$ Brege, H., \& Kindström, D. (2019). Exploring proactive market strategies. Industrial Marketing Management, (March), 1-14.

${ }^{16}$ De Moortel, K., \& Crispeels, T. (2018). International university-university technology transfer: Strategic management framework. Technological Forecasting and Social Change. Vol.135. Hal.145-155.

${ }^{17}$ Wheelen, T.L, \& David Hunger, J.(2015)."Strategic Management and Business Policy Toward Global Sustainability Thirteenth Edition". 
dapat didefinisikan sebagai derivasi tugas yang harus melibatkan banyak pihak ${ }^{18}$.

\section{Pemasaran}

Kotler dan Keller (2016) mendefinisikan pemasaran sebagai proses memperkenalkan nilai dan pesan dari perusahaan kepada konsumen (end user) agar dapat mendapatkan informasi satu sama lain ${ }^{19}$.

\section{Strategi Bersaing}

Strategi bersaing yaitu proses menjalankan bisnis yang dijalankan oleh perusahaan yang bertujuan untuk meningkatkan porsi barang dan jasa sebagai produk sebuah perusahaan ${ }^{20}$. Pada penilaian lain, Porter dan Keller (2016) juga menyatakan bahwa setidaknya harus memiliki tiga keunggulan utuk mampu bersaing, yaitu dengan keunggulan biaya, differensiasi, dan fokus dalam mencetak produk dan jasa untuk memenuhi kebutuhan masyarakat ${ }^{21}$.

\section{Strategi Penantang Pasar}

Strategi penantang pasar ini dapat dilakukan dan diterapkan apabila tujuan perusahaan adalah untuk mendogkrak sumber daya pasar yang pada akhirya ingin menjadi market leader. Maka jelas bahwa tujuan dari strategi penantang pasar adalah untuk meningkatkan pangsa pasar itu sendiri22. Adapula beberapa jenis strategi penantang pasar menurut Kotler dan Keller adalah sebagai berikut:

(1) Serangan frontal adalah serangan secara terangterangan menyamai produk, iklan, harga, dan distribusi dari competitor. Dimana serangan ini

\footnotetext{
${ }^{18}$ P.Stephen, R., \& Coulter, M.(2014)."Manajemen". Jakarta.Erlangga.

${ }^{19}$ Kotler, P., \& Keller, K.L. Op.cit.

${ }^{20}$ Wheelen, T.L., \& David Hunger. Op.cit.

${ }^{21}$ Kotler, P., \& Keller, K.L. Op.cit.

22 Ibid.
} 
menyatakan bahwa pihak yang memiliki sumber daya lebih besar yang akan menang.

(2) Serangan flank adalah serangan yang mengincar titik lemah dari lawan yang dapat diarahkan pada dua dimensi geografis dimana dalam hal ini penyerang memanfaatkan peluang yang belum tersentuh oleh kompetitor, dan segmen dimana penyerang memanfaatkan peluang dengan menyediakan kebutuhan pasar yang belum terpenuhi dengan baik.

(3) Serangan encirclement adalah serangan melalui usaga pegepungan untuk menangkap suatu bagian wilayah kompetitor dengan serangan yang cepat. Serangan ini bisa diterapkan ketika penantang memiliki sumber daya yang unggul dan memiliki keyakinan bahwa pengepungan dengan cepat akan menghancurkan kompetitor.

(4) Serangan by-pass adalah serangan melewati seluruh kompetitor dan menyerang pasar yang lebih mudah di masuki untuk dapat memperluas basis sumber daya perusahaan melalui tiga pendekatan, yaitu diversifikasi produk yang tidak berhubungan, melakukan diversifikasi ke dalam pasar geografis baru, dan melompat ke teknologi baru untuk menggantikan produk yang lama.

(5) Perang gerilya adalah serangan dengan betuk kecil dan tidak teratur seperti menurunkan harga barang, serangan kilat promosi secara intens, ataupun kadang menggunakan tindakan hukum yang bertujuan untuk mempermalukan dan merusak moral kompetitor dan pada akhirnya penyerang akan mendapatkan tempat permanen di pasar.

\section{Analisis SWOT}

SWOT digunakan untuk menentukan ketepatan strategi dalam mengembangkan nilai perusahaan ${ }^{23}$. SWOT juga dapat digunakan sebagai pedoman untuk

${ }^{23}$ Rangkuti, F. Op.cit. 
merencanakan dan mengevaluasi mengenai Kekuatan (streght) merupakan keunggulan yang dimiliki oleh sebuah perusahaan dalam sumber daya, kemampuan, dan keunggulan lain yang muncul dari dalam perusahaan tersebut. Kelemahan (weakness) merupakan keterbatasan atau kekurangan pada sebuah perusahaan yang menghalangi kinerja perusahaan tersebut. Peluang (oppurtunity) merupakan situasi yang menguntungkan bagi perusahaan dalam setiap aspek usaha. Ancaman (treats) merupakan situasi yang tidak menguntungkan bagi perusahaan yang berupa rintangan-rintangan yang sedang dihadapi perusahaan.

Pendekatan kuantitatif analisis SWOT dilakukan dengan melakukan perkalian skor (a) terhadap bobot (b) pada setiap faktor SWOT untuk mendapat total nilai perkalian $(c=a \times b)^{24}$. Penentuan posisi dilakukan dengan mengurangi total nilai perkalian faktor $S$ dengan $W$ untuk mendapat koordinat $x(x=S-W)$ dan mengurangi total nilai faktor $O$ dengan $T$ untuk mendapat koordinat $y$ ( $y=$ $\mathrm{O}-\mathrm{T})$, sehingga didapatkan koordinat $(\mathrm{x}, \mathrm{y})$ untuk menentukan posisi perusahaan pada diagram SWOT. Diagram SWOT terbagi menjadi 4 kuadran yang ditunjukkan pada Gambar 1.

Tujuan mengetahui posisi perusahaan adalah untuk menentukan jenis strategi yang diambil berdasarkan kondisi eksternal dan internal perusahaan ${ }^{25}$. Setiap kuadran dipengaruhi oleh faktor kekuatan, kelemahan, peluang, dan ancaman perusahaan dimana hal itu dijelaskan sebagai berikut dibawah ini ${ }^{26}$ :

(1) Kuadran I

Posisi ini menandakan perusahaan memiliki kekuatan dan peluang yang baik. Rekomendasi strategi pada

\footnotetext{
${ }^{24}$ Pearce, J.A., \& Robinson, R.B.(2013)."Management Strategik. Salemba Empat.

${ }^{25}$ Chang, H.H., \& Huang, W.C.(2006)."Application of a Quantification SWOT Analytical Method". Mathematical and Computer Modelling. Vol.43. No.2. hal.158-169.

${ }^{26}$ Rangkuti. Op.cit.
} 
posisi ini adalah Progresif, dimana perusahaan dapat terus melakukan pengembangan karena memiliki peluang dan kekuatan yang baik.

(2) Kuadran II

Posisi ini menandakan perusahaan memiliki kekuatan yang baik namun memiliki tantangan yang besar. Rekomendasi strategi pada posisi ini adalah Diversifikasi Strategi, perusahaan harus memiliki beberapa strategi lain untuk menghadapi tantangan tersebut.

(3) Kuadran III

Posisi ini menandakan perusahaan yang lemah namun memiliki peluang yang baik. Rekomendasi strategi pada posisi ini adalah Perubahan Strategi, perusahaan harus merubah strateginya untuk memanfaatkan peluang yang ada karena dikhawatirkan strategi yang lama tidak dapat memanfaatkan peluang tersebut.

(4) Kuadran IV

Posisi ini menandakan perusahaan yang lemah dan memiliki ancaman. Rekomendasi strategi pada posisi ini adalah Bertahan, dimana perusahaan berada pada posisi yang dilematis. Strategi bertahan diambil untuk membenahi kondisi internal perusahaan agar tidak semakin terperosok.

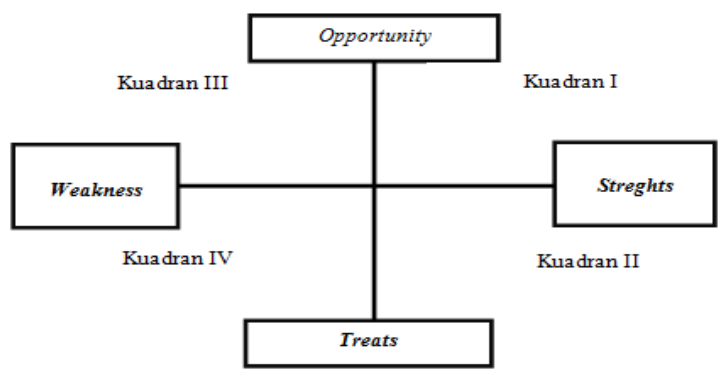

Gambar 1. Diagram SWOT 


\section{Matrik SWOT}

Merupakan alternatif strategi yang dilakukan dengan didasarkan pada hasil identifikasi keadaan internal dan keadaan eksternal sebuah perusahaan atau institusi. Hasil identifikasi tersebut bukanlah hasil dari penilaian dari internal perusahaan atau institusi, namun juga hasil penilaian dari eksternal perusahaan tersebut. Alternatif strategi tersebut dapat dideskripsikan dalam bentuk matrik, sebuah matrik dengan kemungkinan empat opsi strategi ${ }^{27}$.

Pendekatan kualitatif analisis SWOT dapat menghasilkan alternative-alternatif strategi yang dapat diambil perusahaan dengan melihat hubungan faktorfaktor SWOT $^{28}$. Hubungan tiap faktor SWOT akan menghasilkan alternatif strategi SO-ST-WO-WT yang ditunjuk-kan pada tabel 1. Matriks SWOT alternatif strategi tersebut memiliki cara yang berbeda untuk meningkatkan kinerja suatu organisasi ${ }^{29}$.

(1) SO (Strength - Opportunity)

(2) WO (Weakness - Opportunity)

(3) ST (Strength - Threat)

(4) WT (Weakness - Threat)

${ }^{27}$ Sammut-Bonnici, T., \& Galea, D. (2015)."SWOT Analysis". Willey Encyclopedia of Management, hal. 1-8.

${ }^{28}$ Rangkuti, F. Op.cit.

${ }^{29} \mathrm{lbid}$. 
Tabel 1. Matrix SWOT

\begin{tabular}{|c|c|c|c|}
\hline & & Weakness (W) & Streghts(S) \\
\hline 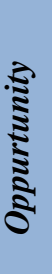 & $\widehat{\vartheta}$ & $\begin{array}{l}\text { Mempertimbangkan strategi } \\
\text { yang memanfaatkan } \\
\text { peluang untuk menghindari } \\
\text { kelemahan } \\
\text { (WO) } \\
\text { [Konservatif/ turnaround] }\end{array}$ & $\begin{array}{l}\text { Mempertimbangkan strategi } \\
\text { yang menggunakan } \\
\text { kekuatan untuk } \\
\text { memanfaatkan peluang. } \\
\text { (SO) } \\
\text { [Agresif] }\end{array}$ \\
\hline $\begin{array}{l}\tilde{\Xi} \\
\vdots \\
\Sigma\end{array}$ & $\mathcal{E}$ & $\begin{array}{l}\text { Mempertimbangkan strategi } \\
\text { yang meminimalkan efek } \\
\text { kelemahan dan mengatasi } \\
\text { atau menghindari ancaman } \\
\text { (WT) } \\
\text { [Defensif] }\end{array}$ & $\begin{array}{l}\text { Mempertimbangkan strategi } \\
\text { yang menggunakan } \\
\text { kekuatan untuk mengatasi } \\
\text { atau menghindari ancaman. } \\
\text { (ST) } \\
\text { [Diversifikasi] }\end{array}$ \\
\hline
\end{tabular}

Analisis SWOT dilakukan berdasarkan hasil identifikasi kondisi eksternal dan internal sebuah organisasi. Identifikasi tersebut tidak hanya berdasarkan sudut pandang perusahaan namun juga perlu melibatkan sudut pandang pihak eksternal seperti konsumen. Penentuan strategi berdasarkan analisis SWOT dapat berakibat pada pengambilan keputusan strategi yang salah karena hanya melibatkan sudut pandang manager ${ }^{30}$. Sudut pandang pelanggan dibutuhkan untuk mengetahui apakah strategi yang diambil oleh perusahaan berpengaruh terhadap pelanggan tersebut.

\section{Metode Penelitian Jenis Data Penelitian}

Data penelitian yang digunakan terdiri dari data primer dan data sekunder. Data primer pada penelitian ini diperoleh secara langsung dari responden melalui

30 Phadermrod, B., Crowder, R. M., \& Wills, G. B. (2019)."ImportancePerformance Analysis based SWOT analysis". International Journal of Information Management, Vol. 44, Hal. 194-203. 
proses in deep interview dan focus group discussion (FGD). Responden berasal dari internal perusahaan PT. FMM, yang berlatar belakang deputy brach managers, manager group. Sedangkan sumber data sekunder dalam penelitian ini adalah segala referensi tertulis seperti laporan keuangan, majalah, jurnal, dan dokumen yang berkaitan.

Tabel 2. Data Responden

\begin{tabular}{|c|c|c|c|}
\hline Charactristics & A & B & C \\
\hline \multicolumn{4}{|l|}{ Gender } \\
\hline Male & $\sqrt{ }$ & $\sqrt{ }$ & $\sqrt{ }$ \\
\hline \multicolumn{4}{|l|}{ Female } \\
\hline \multicolumn{4}{|l|}{ Age } \\
\hline 35-40 Years old & & & $\sqrt{ }$ \\
\hline 40-45 Years old & $\sqrt{ }$ & $\sqrt{ }$ & \\
\hline \multicolumn{4}{|l|}{ Education } \\
\hline Bachelor & $\sqrt{ }$ & $\sqrt{ }$ & $\sqrt{ }$ \\
\hline Work Experience & 14 & 10 & 15 \\
\hline
\end{tabular}

\section{Teknik Pengumpulan Data}

Sesuai dengan pendekatan penelitian yang digunakan yakni pendekatan kualitatif, maka teknik pengumpulan data setidaknya dibagi menjadi 2 tehnik tahapan. Tahapan tersebut meliputi Focus Group Discussion (FGD) dan in deep interview. FGD dilakukan dengan mengundang sejumlah karyawan divisi internal guna mendapatkan gambaran dan wawasan mengenai aktivitas pemasaran dan penjualan sehingga diperoleh bahan untuk menyusun strategi peningkatan pangsa pasar. Wawancara mendalam dilakukan untuk konfirmasi dan klarifikasi data dalam metode triangulasi data, yaitu dengan mewawancarai praktisi yang mempunyai kompetensi dalam bidang pemasaran dan managemen strategik. 


\section{Tahapan Penelitian}

Untuk melakukan analisis SWOT, perlu dilakukan serangkaian tahapan penelitian mengingat tujuannya adalah agar dapat menyusun formula strategi yang akurat dan efektif ${ }^{31}$. Diawali dari perencanaan, observasi pendahuluan, penyusunan konstruksi model, fase analisis hasil sampai dengan tahapan penyusunan laporan tahap akhir penelitian. Tahapan penelitian ini diadopsi dari tahapan penelitian yang awalnya dilakukan oleh Saaty (Ascarya, 2016) dan dikembangkan oleh beberapa ilmuwan termasuk Ascarya, seorang peneliti senior Bank Indonesia (BI), sehingga tersusunlah tahapan penelitian jurnal ini sebagaimana bagan di bawah ini.

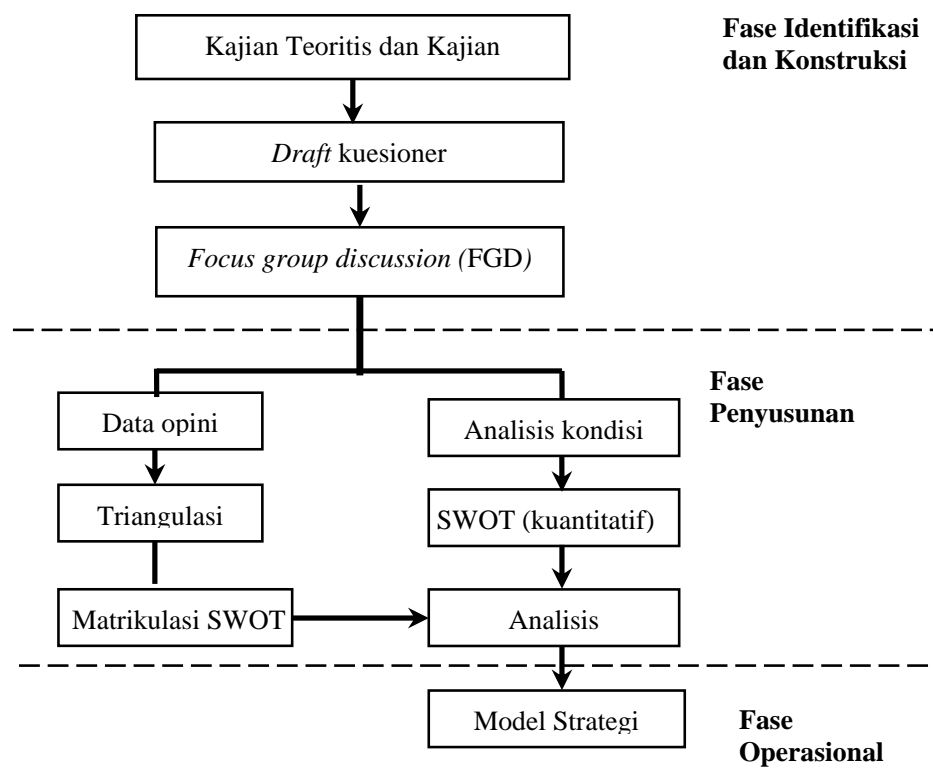

Gambar 2. Tahapan Penelitian

Hasil elaborasi studi literatur dengan mengklasifikasi

${ }^{31}$ Rangkuti. Op.cit. 
dan menyusun draft kuesioner dilanjutkan dengan proses focus group discussion (FGD). FGD diarahkan kepada kegiatan diskusi dengan para direksi perusahaan. Selain kegiatan FGD juga dilakukan kegiatan wawancara mendalam dengan pihak eksternal yaitu komisaris independen perusahaan. Tahapan ini selesai dengan ditandainya usainya proses FGD dan wawancara dengan expertise. Selanjutnya terdapat dua kegiatan. Pertama, analisis SWOT kualitatif yaitu dengan mereduksi pemaparan data dan informasi dan mengolahnya dalam bentuk uraian narasi dan deskripsi. Kedua, analisis SWOT kuantitatif, yaitu dengan mengkodifikasi, menghitung bobot dan rating IFAS dan EFAS yang kemudian disusun matrik SWOT. Dari hasil perhitungan bobot dan penyusunan matrik SWOT, kemudian akan dianalisis dan diperoleh hasil untuk menentukan hasil dan arah kebijakan strategi sesuai kuadran matrik.

\section{Teknik Analisis data}

Teknik yang digunakan dalam mengolah data pada penelitian ini adalah analisis SWOT. Pada analisis SWOT sangat memungkinkan dilakukan penggalian data agar diperoleh formula strategi yang kuat dan efektif ${ }^{32}$. Pada proses identifikasi faktor-faktor yang berada di lini kerja perusahaan, harus diklasifikasikan menjadi 2 yaitu faktor internal dan faktor eksternal. Faktor internal meliputi 2 unsur utama yaitu kekuatan (strenght) dan kelemahan (weakness). Sedangkan untuk faktor eksternal meliputi yaitu peluang (oppurtunity) dan ancaman (treath).

Selain itu, metode analisis ini juga akan membantu memahami situasi atau kondisi saat ini dari perusahaan/industri dan membantu meningkatkan status perusahaan/industri. Sekaligus analisis SWOT akan membantu menemukan solusi terhadap ancaman dan kelemahan, sehingga perusahaan akan tumbuh dan

${ }^{32}$ Rangkuti. Op.cit. 
menjadi kompetitif dan terhadap saingannya ${ }^{33}$.

\section{Teknik Validasi data}

Teknik yang dipakai untuk memvalidasi dan menjaga keobjektifan data dan informasi yang diperoleh dari hasil penelitian lapangan yaitu melalui serangkaian proses dan metode mulai dari FGD, wawancara mendalam dengan para responden. Triangulasi adalah proses konfirmasi data yang dilakukukan baik oleh peneliti maupun tim peneliti, baik berdasarkan waktu pemberian data (triangulasi waktu) maupun berdasarkan sumber pemberi data (triangulasi sumber). Triangulasi data nantinya dilakukan menggunakan in depth interview dengan user atau konsumen dari produk. Tujuannya adalah setelah dari hasil triangulasi tersebut, nantinya diperoleh hasil ulasan dan paparan mengenai kekurangan dan hal inwal lainnya dari produk market challenger tersebut, sehingga akan diperoleh sebuah ulasan pula dalam bentuk poin-poin analisis SWOT yang menjadi unsur penyusun strategi pemasaran produk.

\section{Pembahasan}

\section{Analisis SWOT Kualitatif}

Identifikasi kondisi internal dan eksternal perusahaan distributor tunggal dilakukan dengan melakukan observasi langsung pada proses bisnis perusahaan. Hasil observasi yang dilakukan dengan melihat langsung aktivitas bisnis perusahaan didiskusikan dengan pihak internal manajemen perusahaan dan pihak eksternal yaitu akademisi, dan konsumen.

Hasil diskusi tersebut kemudian divalidasi dan ditetapkan menjadi faktor-faktor yang digunakan pada analisis SWOT proses bisnis perusahaan sebagai berikut. Kekuatan yang dimiliki perusahaan:

${ }^{33}$ Kanat, S., Abbasi, S., Peerzada, M., \& Atilgan, T. (2018). "SWOT Analysis of Pakistan's Textile and Clothing Industry". Industria Textila. Vol.502. 
(1) Harga yang kompetitif.

(2) Kompetensi sales force di atas rata rata.

(3) Support Principal yang bagus.

(4) Adanya Back up unit apabila ada kerusakan.

(5) Kondisi keuangan Perusahaan cukup bagus.

Kelemahan yang dimiliki perusahaan:

(1) Layanan after market yang buruk.

(2) Kualitas Produk kurang bagus.

(3) Support management yang kurang fokus untuk memberikan arahan strategi pemasaran untuk merk YDS.

(4) Brand equity yang belum kuat.

(5) Tidak adanya produk di Teaching Hospital sehingga tidak familiar.

Peluang yang dapat dimanfaatkan perusahaan:

(1) Peluang Bisnis.

(2) Peraturan Pemerintah terkait RS Tipe B.

(3) Kebutuhan akan penegakan diagnosa yang cepat.

Ancaman yang dihadapi perusahaan:

(1) Worth to Mouth yang kurang baik terhadap merk.

(2) Agresivitas competitor.

\section{Analisis SWOT Kuantitatif}

Penentuan posisi perusahaan dengan menggunakan analisis SWOT dilakukan dengan pemberian nilai bobot dan pringkat. Pembobotan dilakukan dengan memilih angka dengan rentang 0,0 sampai 1,0 berdasarkan tingkat kepentingannya, dengan angka 0,0 menunjukkan tidak penting sampai angka 1,0 menunjukkan sangat penting. Pemberian peringkat dilakukan dengan memilih angka 1 sampai 4 berdasarkan tingkat pengaruhnya, dimana angka 1 menunjukkan pengaruh sangat kecil sampai 4 menunjukkan pengaruh sangat besar. Pemberian nilai bobot dan peringkat dilakukan oleh para 
deputy brach managers, manager group sebagai internal perusahaan.

Tabel 3. Kuisioner Analisis SWOT Kuantitatif Kondisi Internal Factor Strategis

\begin{tabular}{|c|c|c|c|c|c|c|}
\hline \multirow{2}{*}{$\begin{array}{c}\text { Faktor Strategis Internal (IFAS) } \\
\text { (a) }\end{array}$} & \multirow{2}{*}{$\begin{array}{l}\text { Bobot } \\
\text { (b) }\end{array}$} & \multicolumn{4}{|c|}{ Rating (c) } & \multirow{2}{*}{$\begin{array}{l}\text { Skor }(b \times c) \\
\text { (d) }\end{array}$} \\
\hline & & Responden 1 & Responden 2 & Responden 3 & Rata - Rata & \\
\hline \multicolumn{7}{|l|}{ KEKUATAN } \\
\hline Harga yang kompetitif ( S1) & 0.025 & 4.00 & 3.00 & 4.00 & 3.67 & 0.09 \\
\hline $\begin{array}{l}\text { Kompetensi sales force di atas rata rata } \\
\text { (S2) }\end{array}$ & 0.025 & 4.00 & 3.00 & 4.00 & 3.67 & 0.09 \\
\hline Support Principal yang bagus (S3) & 0.025 & 4.00 & 3.00 & 3.00 & 3.33 & 0.08 \\
\hline $\begin{array}{l}\text { Adanya Back up unit apabila ada } \\
\text { kerusakan ( } 44 \text { ) }\end{array}$ & 0.025 & 4.00 & 4.00 & 4.00 & 4.00 & 0.10 \\
\hline $\begin{array}{l}\text { Kondisi keuangan perusahaan cukup } \\
\text { bagus (S5) }\end{array}$ & 0.050 & 3.00 & 3.00 & 3.00 & 3.00 & 0.15 \\
\hline \multicolumn{7}{|l|}{ KELEMAHAN } \\
\hline Layanan after market yang buruk (W1) & 0.200 & 2.00 & 2.00 & 2.00 & 2.00 & 0.40 \\
\hline Kualitas Produk kurang bagus (W2) & 0.100 & 2.00 & 1.00 & 2.00 & 1.67 & 0.17 \\
\hline $\begin{array}{l}\text { Support management yang kurang fokus } \\
\text { untuk memberikan arahan strategi } \\
\text { pemasaran untuk merk YDS (W3) }\end{array}$ & 0.050 & 2.00 & 1.00 & 2.00 & 1.67 & 0.08 \\
\hline Brand Equity yang belum kuat (W4) & 0.250 & 1.00 & 1.00 & 1.00 & 1.00 & 0.25 \\
\hline $\begin{array}{l}\text { Tidak adanya produk di Teaching } \\
\text { Hospital sehingga tidak familiar (W5) }\end{array}$ & 0.250 & 1.00 & 1.00 & 1.00 & 1.00 & 0.25 \\
\hline TOTAL & 1.00 & & & & & 1.67 \\
\hline
\end{tabular}

Berdasarkan hasil analisis SWOT kuantitatif terhadap faktor internal PT. FMM pada Tabel 3, diketahui bahwa terdapat lima faktor kekuatan dan lima faktor kelemahan pada kondisi internal perusahaan. Nilai total faktor kekuatan dan kelemahan kondisi internal perusahaan adalah $+1,67$. Ini menandakan bahwa factor internal bisnis sedang mengalami kondisi yang buruk. Sedangkan evaluasi kondisi internal berdasarkan nilai faktor kekuatan dikurangi kelemahan perusahaan adalah sebesar -0,63. Sehingga perusahaan seharusnya meningkatkan lagi kinerjanya dengan memperbaiki kondisi internal dan menghilangkan kelemahan yang ada. 
Tabel 4. Kuisioner Analisis SWOT Kuantitatif Kondisi Eksternal Factor Strategis

\begin{tabular}{|c|c|c|c|c|c|c|}
\hline \multirow{2}{*}{$\begin{array}{c}\text { Faktor Strategis Eksternal (EFAS) } \\
\text { (a) }\end{array}$} & \multirow{2}{*}{$\begin{array}{l}\text { Bobot } \\
\text { (b) }\end{array}$} & \multicolumn{4}{|c|}{ Rating (c) } & \multirow{2}{*}{$\begin{array}{c}\text { Skor (b x c) } \\
\text { (d) }\end{array}$} \\
\hline & & Responden 1 & Responden 2 & Responden 3 & Rata - Rata & \\
\hline \multicolumn{7}{|l|}{ PELUANG } \\
\hline Peluang Bisnis (O1) & 0.250 & 4.00 & 3.00 & 4.00 & 3.67 & 0.92 \\
\hline $\begin{array}{l}\text { Peraturan Pemerintah terkait RS Tipe B } \\
\text { (O2) }\end{array}$ & 0.300 & 4.00 & 3.00 & 3.00 & 3.33 & 1.00 \\
\hline $\begin{array}{l}\text { Kebutuhan akan penegakan diagnosa } \\
\text { yang cepat }(\mathrm{O} 3)\end{array}$ & 0.050 & 3.00 & 3.00 & 3.00 & 3.00 & 0.15 \\
\hline \multicolumn{7}{|l|}{ ANCAMAN } \\
\hline $\begin{array}{l}\text { Worth to Mouth yang kurang baik } \\
\text { terhadap merk (T1) }\end{array}$ & 0.300 & 2.00 & 2.00 & 1.00 & 1.67 & 0.50 \\
\hline Agresivitas Kompetitor (T2) & 0.100 & 1.00 & 1.00 & 1.00 & 1.00 & 0.10 \\
\hline TOTAL & 1.00 & & & & & 2.67 \\
\hline
\end{tabular}

Berdasarkan hasil analisis SWOT kuantitatif terhadap faktor internal perusahaan distributor tunggal pada Tabel 5, diketahui bahwa terdapat tiga faktor peluang dan dua faktor ancaman pada kondisi internal perusahaan. Nilai total faktor peluang dan ancaman kondisi eksternal perusahaan adalah $+2,67$. Hal itu menandakan bahwa factor eksternal bisnis cukup menjanjikan. Sedangkan evaluasi faktor eksternal total skor peluang dikurangi dengan ancaman adalah sebesar $+1,47$. Adapun nilai tersebut menunjukkan bahwa perusahaan belum memanfaatkan peluang dengan baik dan meredam ancaman.

\section{Diagram SWOT}

Di dalam analisis Diagram SWOT ini menggunakan data hasil pengolahan kuisioner seperti yang tercantum pada Tabel $3 \& 4$. Dengan keduat tabel tersebut akan didapat skor yang menunjukkan identifikasi faktor-faktor yang digunakan untuk merumuskan dan Focus Discusion Group strategi perusahaan. Analisis SWOT ini merupakan awal proses perumusan strategi yang akan dilakukan untuk membantu penentuan strategi yang akan diambil oleh perusahaan distributor tunggal.

Hasil perhitungan analisis SWOT kuantitatif pada kondisi internal dan eksternal perusahaan distributor tunggal menunjukkan skor nilai internal sebesar $-0,63$ 
dan skor nilai eksternal sebesar $+1,47$ seperti yang ditunjukkan pada diagram SWOT dibawah ini. Nilai skor internal menunjukkan posisi koordinat $\mathrm{x}$ dan nilai skor eksternal menunjukkan posisi koordinat $y$, sehingga posisi perusahaan berada pada kuadran III pada titik koordinat $(-0,63 ;+1,47)$ jadi strategi yang harus diambil adalah Turnaround, dimana perusahaan harus merubah strateginya untuk memanfaatkan peluang yang ada karena dikhawatirkan strategi yang lama tidak dapat memanfaatkan peluang yang ada.

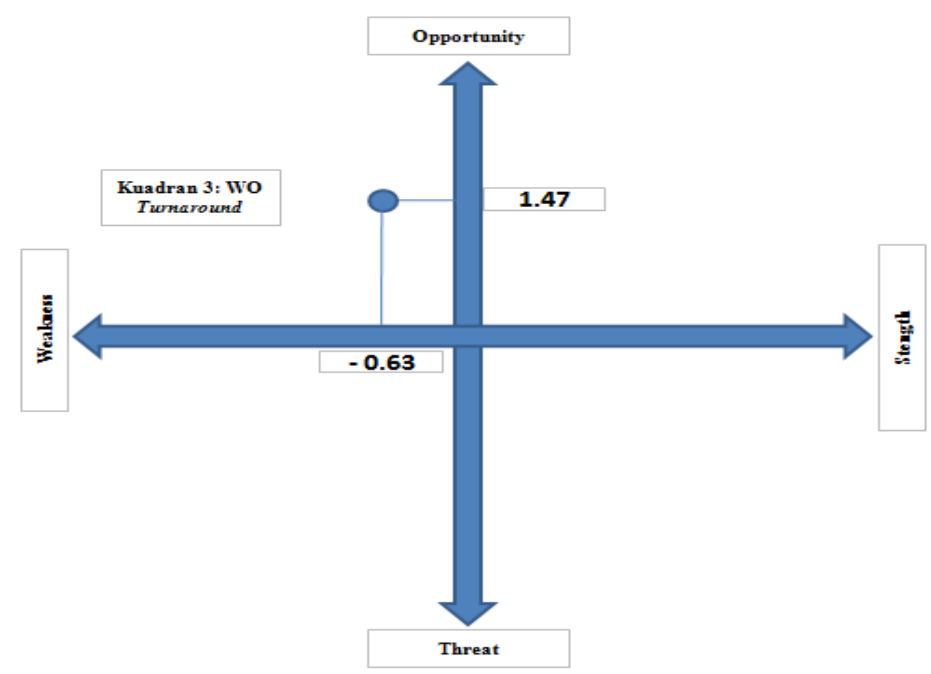

Gambar 3. Diagram SWOT Kondisi Perusahaan

\section{Matrik SWOT}

Faktor-faktor yang telah diidentifikasi dalam analisis SWOT kemudian disusun ke dalam matriks SWOT. Faktor-faktor tersebut mewakili kondisi internal dan eksternal perusahaan. Berdasarkan hasil diskusi dengan manajemen perusahaan distributor tunggal setelah melihat kondisi internal dan eksternal tersebut, dirumuskan beberapa alternatif strategi yang diharapkan dapat diimplementasikan pada perusahaan untuk 
meningkatkan kinerja perusahaan. Alternatif strategi yang dapat diambil oleh perusahaan adalah sebagai berikut.

Berdasarkan Tabel 5 terdapat empat macam strategi alternatif yang dapat digunakan berdasarkan kondisi eksternal dan internal perusahaan yaitu SO (StrengthOpportunity), ST (Strength-Threat), WO (WeaknesessOppor-tunity), dan WT (Weaknesess-Threat). Berikut merupakan penjelasan alternatif-alternatif strategi pada masing-masing strategi:

(1) Strategi SO

Setelah mengetahui kekuatan yang dimiliki perusahaan untuk memanfaatkan peluang yang ada dengan meningkatkan kualitas dan kuantitas calls sales force serta melakukan bundling produk penunjang.

(2) Strategi ST

Setelah mengetahui kekuatan yang dimiliki perusahaan untuk mengatasi atau meredam ancaman dengan melakukan join visit ke RS secara kepada customer kunci, mengambil sales force competitor, dan melakukan re training kepada operator.

(3) Strategi WO

Memanfaatkan peluang yang dimiliki perusahaan untuk menghidar kelemahan yang ada dengan meningkatkan kompetensi karyawan after market sehinggan pelayanan lebih cepat dan tepat, melakukan perbaikan kualitas produk, dan melakukan kerjasama dengan RS Pendidikan.

(4) Strategi WT

Mempertimbangkan strategi yang meminimalkan efek kelemahan yang dimiliki oleh perusahaan dan mengatasi atau menghindari ancaman yang datang dari luar perusahaan dengan memberikan perhatian secara fokus pada pelayanan di existing customer. 
Tabel 5. Matrik SWOT Alternatif Strategi Perusahaan

\begin{tabular}{|c|c|c|}
\hline IFAS & $\begin{array}{l}\text { STRENGHTS } \\
\text { Harga yang kompetitif (S1) } \\
\text { Kompetensi sales force di atas rata rata (S2) } \\
\text { Support Principal yang bagus ( S3) } \\
\text { Adanya Back up unit apabila ada kerusakan (S4) } \\
\text { Kondisi keuangan Perusahaan cukup bagus (S5) }\end{array}$ & $\begin{array}{l}\text { WEAKNESSES } \\
\text { Layanan after market yang buruk (W1) } \\
\text { Kualitas Produk kurang bagus (W2) } \\
\text { Support management yang kurang folus } \\
\text { untuk memberikan arahan strategi pemasaran } \\
\text { untuk merk yds (W3) } \\
\text { Brand equity yang belum kuat (W4) } \\
\text { Tidak adanya produk di Teaching Hospital } \\
\text { sehingga tidak familiar (W5) }\end{array}$ \\
\hline $\begin{array}{l}\qquad \text { OPPORTUNIES } \\
\text { Peluang Bisnis (O1) } \\
\text { Peraturan Pemerintah terkait RS } \\
\text { Tipe B (O2) } \\
\text { Kebutuhan akan penegakan } \\
\text { diagnosa yang cepat (O3) }\end{array}$ & $\begin{array}{l}\text { Strategi SO } \\
\text { Meningkatkan kuantitas dan kualitas calls sales } \\
\text { force (S1, S2, S3, S4, S5, O1, O2, O3) } \\
\text { Melakukan bundling produk penunjang. (S5, O1, } \\
\text { O2) }\end{array}$ & $\begin{array}{l}\text { Strategi WO } \\
\text { Meningkatkan kompetensi karyawan after } \\
\text { market sehinggan pelayanan lebih cepat dan } \\
\text { tepat (W1, W3,W3 O1, O2) } \\
\text { Melakukcan perbaikan kualitas produk (W2, } \\
\text { O1, O2) } \\
\text { Melakukcan kerjasama dengan RS Pendidikan } \\
\text { (W5, O1, O2 dan O3) }\end{array}$ \\
\hline $\begin{array}{l}\text { THREAT } \\
\text { Worth to Mouth yang kurang baik } \\
\text { terhadap merk (T1) } \\
\text { Agresivitas Kompetitor (T2) }\end{array}$ & $\begin{array}{l}\text { Strategi ST } \\
\begin{array}{l}\text { Melakukan join visit ke RS secara kepada } \\
\text { customer kunci (S2, S3, S4, S5, T1) }\end{array} \\
\text { Mengambil Sales force Competitor (S5, T4) } \\
\text { Melakukan re training kepada operator (S5, T1) }\end{array}$ & $\begin{array}{l}\text { Strategi WT } \\
\text { Folus pada pelayanan di existing customer } \\
\text { (W1, T2) }\end{array}$ \\
\hline
\end{tabular}

\section{Penut}

up

(1) Dari analisis SWOT kuantitatif faktor internal menunjukan bahwa perusahaan seharusnya meningkatkan kembali kinerja yang dimiliki dengan memperbaiki kondisi internal dan menghilangkan kelemahan yang ada. Sedangkan Dari analisis SWOT kuantitatif faktor eksternal menunjukan bahwa perusahaan belum memanfaatkan peluang dengan baik dan meredam ancaman dari luar.

(2) Perusahaan harus merubah strategi lama yaitu strategi serangan frontal dengan strategi baru serangan encirclement dengan menghilangkan kelemahan melalui cara peningkatkan kompetensi karyawan after market sehinggan pelayanan lebih cepat dan tepat, melakukan perbaikan kualitas produk, melakukan kerjasama dengan RS Pendidikan. Adapun untuk meredam ancaman melalui cara memberikan perhatian secara fokus pada pelayanan di existing customer. 
(3) Dari matrik SWOT didapatkan empat strategi alternatif. SO-WO-ST-WT.

(4) Sebagai strategi yang tepat untuk penantang pasar adalah Serangan encirclement atau pengepungan merupakan usaha untuk menangkap suatu bagian wilayah kompetitor dengan serangan yang cepat. Mengepung dapat diterapkan ketika penantang memiliki sumber daya yang unggul dan yakin bahwa pengepungan dengan cepat akan menghancurkan moral yang dimiliki kompetitor.

\section{Saran}

(1) Topik menarik berikutnya yang terkait dengan pengembangan penelitian ini diantaranya adalah Product Brand equity. Hal tersebut dikarenakan salah satu strategi perusahaan dalam meningkatkan market share adalah dengan meningkatkan kunci kekuatan suatu produk di mana yang akan lebih di teliti kembali adalah Brand awareness, Brand Image, Perceived quality dan Brand Loyalti sehingga dapat memberi masukan yang lebih rigid bagi perkembangan sales pada seluruh perusahaan yang memiliki bidang bisnis yang memiliki kesamaan dengan PT. FMM.

(2) Menggunakan tools ANP untuk mengkuantifikasi hasil analisis SWOT supaya menghasilkan pemilihan alternatif strategi yang lebih akurat.

(3) Mencoba menggunakan metode lain selain analisis SWOT untuk mengetahui hasil dari metode tersebut yang kemudian dibandingkan dengan metode analisis SWOT untuk mendapatkan solusi yang lebih baik. 


\section{Daftar Referensi}

Kementrian Kesehatan RI. 2015. Pusat Data Dan Informasi Kementrian Kesehatan RI.

Kementrian Kesehatan Republik Indonesia. 2014. Peraturan Menteri Kesehatan Republik Indonesia No 56 Tahun 2014.

http://www.yankes.kemkes.go.id/assets/downloa ds/PMK\%20No.\%2056\%20ttg\%20Klasifikasi\%20d an\%20Perizinan\%20Rumah\%20Sakit.pdf.

Kotler, Philip, and Kevin Lane Keller. (2016). Pearson Marketing Management 14e. Pearson Education Limited.

Rahmayati HM. (2015)." Analisis SWOT dalam

Menentukan Strategi Pemasaran Udang Beku PT.

Mustika Mina Nusa Aurora Tarakan, Kalimantan

Utara". Jurnal Galung Tropika. Vol.4 No.1.

hal.60-67.

Iman Sulaeman. (2016)." Kualitas Pelayanan dan Strategi Marketing Terhadap Kepuasan Pada Suria City Hotel Bandung". Jurnal Lentera Bisnis. Vol.5 No.2. hal. 77-103.

Dr. Fahreza Zafar, Sman Babar, dkk. (2013)." The Art of Strategic Management - a key success in corporate sector". EuropeanJournal of Research and Reflection in Management Sciences. Vol.1 No.1. Hal.15-24.

Aries Susanty \& Woro Widiati. (2014)."Pemilihan Strategi Pemasaran di Kampoeng Kopi Banaran Menggunakan Pendekatan Metode Analytical 
Network Process (anp) dan Technique for Order Preference by Similarity To an Ideal Solution (TOPSIS)". J@TI Undip. Vol IX No 3. Hal.163-172.

Ifediora Christian Osita \& Idoko Onyebuchi R., dkk. (2014)." Organization's stability and productivity the role of SWOT analysis an acronym for strenght, weakness, oppurtunities and threat". International Journal of Innovative and Applied Research. Vol.2 No.9. Hal.23-32.

Živan Živković \& Djordje Nikolić, dkk. (2015)." Analytical Network Process in the Framework of SWOT Analysis for Strategic Decision Making (Case Study: Technical Faculty in Bor, University of Belgrade, Serbia). Acta Polytechnica Hungarica. vol.12 No.7. Hal.199-216.

Ilyas \& Sarika Zuhri, dkk. (2018)." Marketing Strategy Determination by SWOT and ANP Approaches on Aceh Songket Small-Medium Enterprises". International Journal of Conceptionson Computing and Information Technology. Vol.6 No.1. Hal.8-13.

Siti Muhimatul Khoiroh. (2017)." Optimalisasi Pengembangan Kampung Industri Batik Tulis Daerah berdasarkan Mapping Value Chain". Surakarta. Seminar dan Konferensi Nasional IDEC 2017.

Al-Refaie, A \& Sy, E, dkk. (2016)." Integration of SWOT and ANP for effective strategic planning in the cosmetic industry".

AdvancesinProductionEngineering\&Management. Vol.11 No.1. Hal.49-58.

Rangkuti, F.(2017).”Teknik Membedah Kasus Bisnis Analisis SWOT, Cara Perhitungan Bobot, Rating, dan OCAL. 
Jakarta. PT Gramedia Pustaka Utama.

Wheelen, T.L, \& David Hunger, J.(2015)."Strategic Management and Business Policy Toward Global Sustainability Thirteenth Edition".

P.Stephen, R., \& Coulter, M.(2014)."Manajemen". Jakarta.Erlangga.

Pearce, J.A., \& Robinson, R.B.(2013)."Management Strategik. Salemba Empat.

Chang, H.H., \& Huang, W.C. (2006)." Application of a Quantification SWOT Analytical Method". Mathematical and Computer Modelling. Vol.43. No.2. hal.158-169.

Sammut-Bonnici, T., \& Galea, D. (2015)."SWOT Analysis". Willey Encyclopedia of Management, hal. 1-8.

Phadermrod, B., Crowder, R. M., \& Wills, G. B. (2019). "Importance-Performance Analysis based SWOT analysis". International Journal of Information Management, Vol. 44, Hal. 194-203.

Yin,R.(2015)."Studi kasus: Desain dan metode". PT Raja Grafindo Persada.

Kanat, S., Abbasi, S., Peerzada, M., \& Atilgan, T. (2018). "SWOT Analysis of Pakistan's Textile and Clothing Industry". Industria Textila. Vol.502.

Brege, H., \& Kindström, D. (2019). Exploring proactive market strategies. Industrial Marketing Management, (March), 1-14. 
De Moortel, K., \& Crispeels, T. (2018). International university-university technology transfer: Strategic management framework. Technological Forecasting and Social Change. Vol.135. Hal.145155. 